\title{
Perancangan Perbaikan Proses Produksi Komponen Bodi Mobil Daihatsu dengan Lean Manufacturing di PT. "XYZ"
}

Satria Khalif Isnain 1 , Putu Dana Karningsih ${ }^{2}$

${ }^{1}$ Magister Manajemen Teknologi, Institut Teknologi Sepuluh Nopember Surabaya

${ }^{2}$ Fakultas Teknologi Industri, Institut Teknologi Sepuluh Nopember Surabaya

\begin{tabular}{|c|c|}
\hline INFO ARTIKEL & Abstract \\
\hline \multirow[t]{2}{*}{$\begin{array}{l}\text { Keywords: } \\
\text { Lean Manufacturing, Vsm, } 5 \\
\text { why's, Fmea, Net Nresent } \\
\text { Value }\end{array}$} & $\begin{array}{l}\text { Astra Daihatsu Motor Company. Potential market for automotive is } \\
\text { continuously growing which is positive signal for automotive busi- } \\
\text { nesses. However nowadays competition is also getting stronger. There- } \\
\text { fore PT Inti Pantja Press Industri should efficiently manage their pro- } \\
\text { duction. One way is by reducing and eliminating waste in its produc- } \\
\text { tion. Production process in PT. Inti Pantja Press Industri is still hav- } \\
\text { ing several problems. Based on early observation there are bottleneck } \\
\text { in subassy processes and also defective product. Reffering to these } \\
\text { problems, it can be indicated that there are several waste in production } \\
\text { process of PT. Inti Pantja Press Industri.Therefore, Lean Manufactur- } \\
\text { ing approach is utilized to reduce or eliminate waste in produc- } \\
\text { tion processes. First, various waste are identified using Value Stream } \\
\text { Mapping. Borda Count Method is used for determining critical waste } \\
\text { that occur, they are as follow: waste waiting, defect, and overproduc- } \\
\text { tion that cause over inventory finish product. Then, } 5 \text { Whys Analysis } \\
\text { specifies root causes of waste waiting and waste defect. By using Fail- } \\
\text { ure Mode and Effect Analysis, highest priority of root causescan be } \\
\text { selected, which are operator do not clean dies before press process, } \\
\text { operator do not replace components that has already over its lifetime } \\
\text { (wear) and rust on finish product part. Recommendations for im- } \\
\text { provements are conducted by implementating Poka Yoke method, they } \\
\text { are: installation of sensors and equipment in Press machines and } \\
\text { wrapping finish part product. }\end{array}$ \\
\hline & Abstraks \\
\hline $\begin{array}{l}\text { Kata Kunci: } \\
\text { Lean Manufacturing, Vsm, } \\
\text { 5why's, Fmea, Benefit Cost } \\
\text { Ratio }\end{array}$ & $\begin{array}{l}\text { PT. Inti Pantja Press Industri merupakan produsen komponen- } \\
\text { komponen bodi mobil Daihatsu merk Xenia, Terios, Ayla, Sirion } \\
\text { dan Sigra berlokasi di Bekasi. Industri otomotif memiliki potensi } \\
\text { bisnis yang positif karena permintaan mobil yang terus bertambah }\end{array}$ \\
\hline DOI: & $\begin{array}{l}\text { setiap waktu. Namun, agar dapat memenangkan kompetisi bisnis } \\
\text { yang saat ini semakin berat, maka PT. IPPI harus dapat menjalankan } \\
\text { produksi secara lebih efisien. Hasil observasi awal pada proses } \\
\text { produksi Daihatsu Xenia terindikasi beberapa masalah yang terkait } \\
\text { dengan adanya pemborosan (waste) misalnya bottleneck dan cacat. } \\
\text { Berdasarkan permasalahan yang terjadi, pendekatan lean } \\
\text { manufacturing dipergunakan untuk menyelesaikan permasalahan } \\
\text { tersebut. Pertama-tama pemborosan diidentifikasi dengan Value } \\
\text { Stream Mapping kemudian Borda Count Method dipergunakan untuk } \\
\text { menentukan pemborosan (waste) kritis pada lantai produksi yang } \\
\text { hasilnya yaitu waste waiting, defects dan over production yang } \\
\text { menyebabkan terjadinya over inventory finish part. Metode } 5\end{array}$ \\
\hline
\end{tabular}




\begin{tabular}{|l|l|l|}
\hline & $\begin{array}{l}\text { Whys kemudian dipergunakan untuk mencari akar penyebab } \\
\text { pemborosan (waste). Berdasarkan Failure Mode and Effect Analysis } \\
\text { diketahui akar penyebab waste tertinggi adalah operator tidak } \\
\text { membersihkan dies sebelum proses press, lifetime komponen yang } \\
\text { telah habis namun tidak diganti dan karat pada produk finish part. } \\
\text { Rekomendasi perbaikan yang dapat diusulkan yaitu penerapan } \\
\text { metode Poka Yoke dengan instalasi sensor dan peralatan di mesin } \\
\text { press dan pemasangan wrapping pada pallet produkfinish part. }\end{array}$ \\
\hline $\begin{array}{l}\text { Koresponsi: } \\
\text { Nama: Uswatun Hasanah } \\
\text { Email: uswa@gmail.com, p-ISSN: 2355-9543 } \\
\text { email uswa@gmail.com }\end{array}$ & $\begin{array}{l}\text { ISSN: } \\
\text { 2355-9543(Print) } \\
\text { ISSN: 2460-3775 } \\
\text { (on-line) }\end{array}$ \\
\hline
\end{tabular}

\section{PENDAHULUAN}

Persaingan pasar global semakin ketat membuat perusahaan berlomba-lomba

memberikan layanan terbaik bagi pelanggan melalui penyerahan produk tepat waktu hal ini menuntut perusahaan untuk terus melakukan perbaikan dan peningkatan kinerjanya. Permasalahan yang paling penting dihadapi oleh perusahaan hari ini adalah bagaimana memberikan produk atau material mereka secara cepat dengan biaya yang rendah dan kualitas yang baik (Holweg, 2007). Perfomansi dari perusahaan manufaktur dapat diukur dari efisiensi dan efektivitas pada sistem produksi perusahaan. Sistem produksi perusahaan manufaktur yang efektif dan efisien akan menghasilkan produk yang berkualitas dan kompetitif. Tantangan penting dalam persaingan global adalah efisiensi dari perusahaan dan daya saing membuat perusahaan manufaktur untuk merencanakan strategi manajemen manufaktur baru (Zahraee et. al., 2014).

Industri otomotif di Indonesia memiliki potensi yang besar. Hal ini berdasarkan oleh data penjualan mobil di Indonesia yang cukup tinggi, jika dibandingkan dengan negara-negara lain di ASEAN (Gabungan Industri Kendaraan Bermotor Indonesia,

2015). Selain itu produksi mobil di Indonesia juga mengalami peningkatan setiap tahunnya, hal ini didasarkan dari data produksi mobil di Indonesia. Berdasarkan Gambar 1.1 terlihat bahwa produksi mobil di Indonesia selalu meningkat setiap tahunnya kecuali pada tahun 2006, 2009, dan 2015. Hal ini menunjukkan bahwa industri otomotif di Indonesia mengalami kecenderungan untuk meningkat dan memiliki peluang yang masih sangat besar. Penurunan penjualan di tahun 2014 karena imbas kenaikan harga bahan bakar minyak (BBM) bersubsidi yaitu sebesar Rp. 2.000 per liter untuk premium dan solar serta pertumbuhan ekonomi di Indonesia yang tidak sebesar tahun-tahun sebelumnya.

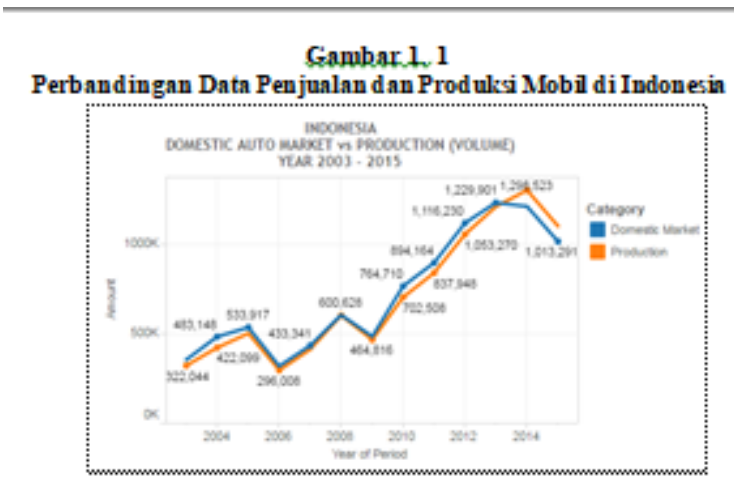

Salah satu industri otomotif di Indonesia yang bergerak di bidang produksi bodi mobil adalah PT. IPPI (Inti Pantja Press Industri). PT. IPPI yang tergabung dalam group Astra Motor 3 merupakan produsen komponen-komponen otomotif terutama yang berkaitan dengan proses press/ stamping. Produksi bodi mobil yang dihasilkan PT. IPPI untuk customer PT. ADM (PT. Astra Daihatsu Motor) yaitu produk bodi mobil Daihatsu merupakan produk dengan volume yang. Jumlah produksi mobil Daihatsu mengalami peningkatan setiap tahunnya (Gaikindo, 2015). Namun terjadi penurunan produksi pada tahun 2015, hal ini berpengaruh juga pada penurunan produksi bodi mobil Daihatsu oleh PT. IPPI. Pada Gambar 1.2 terlihat bahwa produksi mobil Daihatsu pada tahun 2013 dan 2014 sebesar 515.416 unit dan 519.876 unit namun pada tahun 2015 terjadi penurunan menjadi sebesar 455.280 unit, hal ini tidak hanya terjadi di Indonesia tetapi juga secara global karena disebabkan oleh kondisi ekonomi global seperti ketidak stabilan ekonomi di Yunani 


\section{Perancangan Perbaikan Proses Produksi Komponen,.. Satria Khalif Isnain1, Putu Dana Karningsih2}

dan Tiongkok yang berdampak negatif pada kondisi ekonomi di Indonesia dan negara-negara di ASEAN. Namun pada tahun 2016 ini produksi mobil Daihatsu akan kembali meningkat karena PT. Astra Daihatsu Motor menetapkan target nasional penjualan mobil Daihatsu sebesar 1.050 .000 unit, yang menjadikan produksi bodi mobil di PT. IPPI akan meningkat juga

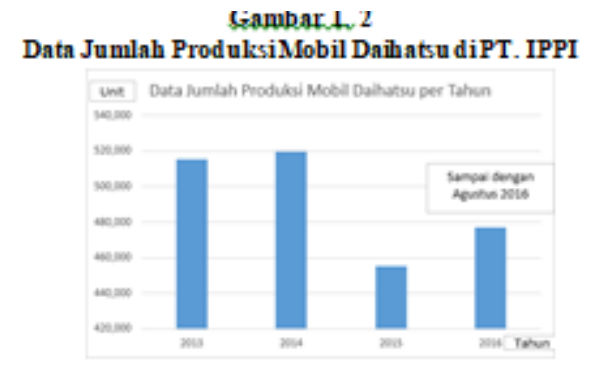

Untuk mencapai sistem produksi yang lebih efektif dan efisien maka seluruh perusahaan yang berada dalam Astra Motor grup menerapkan program untuk mencapai perbaikan yang berkelanjutan misalnya Lean manufacturing, Kaizen, dan lain sebagainya. Seluruh proses di manufaktur PT. IPPI mulai dari input bahan raw material dilakukan proses shearing, stamping, handwork dan sub-assy lalu dihasilkan body/ part body mobil. Layout proses produksi di PT. Inti Pantja Press Industri dapat dilihat pada Gambar 1.3. Proses shearing merupakan proses pemotongan material sheet sesuai dengan kebutuhan komponen bodi mobil yang diperlukan, proses ini menggunakan mesin yang sudah diatur secara otomatis untuk berbagai variasi dimensi pemotongan.

Proses pengepresan (stamping) adalah proses pencetakan metal secara dingin dengan menggunakan dies dan mesin press umumnya plate yang dicetak, untuk menghasilkan produk bodi kendaraan. Lembaran-lembaran baja dicetak menjadi bagian- bagian dari bodi kendaraan seperti bodi mobil, pintu, kap mesin dan atap. Proses handwork adalah proses pengerjaan untuk produk yang cacat setelah proses stamping. Kemudian proses sub-assy merupakan proses perakitan dua komponen atau lebih menjadi satu part bagian sesuai kebutuhan.

Berdasarkan observasi awal di lapangan, saat ini proses produksi di PT. IPPI memiliki beberapa masalah yaitu yang pertama adalah delivery emergency. Delivery emergency merupakan pengiriman yang dilakukan oleh PT. IPPI karena waktu penyelesaian produk melebihi dari jadwal pengiriman yang telah ditentukan oleh customer.
Delivery emergency terjadi karena adanya delay produksi yang disebabkan oleh adanya produk yang gagal produksi karena material/ dies mengalami trouble/ downtime yang menyebabkan terjadinya delay delivery ke customer sehingga berakibat diperlukan tambahan cost sendiri untuk melakukan pengiriman. Berdasarkan Tabel 1.1 terlihat bahwa biaya delivery emergency pada tiap bulan dari awal tahun 2016 dibawah batas yang telah ditentukan, namun pada bulan Juli cost delivery emergency sebesar Rp 7.956 .000 melebihi batas maksimal/plafon yang ditentukan setiap bulannya hanya sebesar Rp 4.500.000.

Tabel 1, 1
\begin{tabular}{|c|c|c|c|c|c|c|c|c|}
\hline \multirow{2}{*}{} & \multirow{2}{*}{ Unit } & & \multicolumn{7}{|c|}{2016} \\
\cline { 3 - 9 } & & Jan & Feb & Mar & Apr & May & Jun & Jul \\
\hline Plan & Rp'000 & 4,500 & 4,500 & 4,500 & 4,500 & 4,500 & 4,500 & 4,500 \\
\hline Actual & Rp'000 & 2,436 & 1,974 & 822 & 372 & 3,348 & 4,062 & 7,956 \\
\hline
\end{tabular}
Sumber: PT.Inti Pantja Press Industri 2016

Masalah yang kedua yaitu terjadi penumpukan atau over stockinventory finish part karena terdapat produksi item/ part diluar jadwal produksi yang ditentukan. Hal ini menyebabkan penyimpanan inventory melebihi volume gudang. Part yang terlalu lama disimpan di gudang juga dapat mengakibatkan terjadinya karat sehingga membutuhkan tambahan biaya untuk maintain (menghilangkan karat) sebelum dikirimkan ke customer. Masalah yang ketiga yaitu defect yang disebabkan oleh beberapa hal seperti dies/ tool mengalami trouble atau kotor, operator mesin maupun material sheet. Permasalahan defect mengakibatkan perlu dilakukannya proses rework yang menyebabkan diperlukan tambahan biaya untuk produk defect. Produk rework merupakan produk defect yang masih bisa diperbaiki atau diproses ulang yang berarti masih menambah biaya produksi untuk alokasi man power melakukan proses rework serta waktu penyelesaian produk bisa melebihi jadwal. Sedangkan produk reject

merupakan produk defect yang tidak dapat dilakukan proses rework atau produk yang tidak diterima customer sehingga produk akan menjadi scrap padahal sudah melalui proses produksi dan menimbulkan biaya produksi tambahan. 


\section{Jurnal Studi Manajemen dan Bisnis \\ Vol. 5 (2) 2018}

Berdasarkan permasalahan yang terjadi tersebut, maka dapat diindikasikan bahwa pada proses produksi masih terdapat adanya pemborosan (waste) akibat delay produksi, over inventory finish part dan defect yang berdampak pada tambahan biaya dan mengurangi efisiensi produksi. Waste mencakup semua kegiatan yang menggunakan sumber daya tetapi tidak menambah nilai secara signifikan untuk pelanggan (Rohani \& Zahraee, 2015). Produk yang dipilih dalam penelitian ini yaitu Daihatsu Xenia item NX2940 Member Sub Assy Floor Side Inner Rh (Rhd) merupakan part di bagian dalam di samping kanan pintu mobil, produk ini dipilih karena produk ini memiliki volume terbesar yang diproduksi, melewati seluruh proses manufaktur yang ada di PT. Inti Pantja Press Industri, dan diproduksi setiap hari serta dilakukan pengiriman ke customer setiap hari.

Berdasarkan permasalahan yang telah dirumuskan, maka tujuan yang ingin dicapai dalam penelitian ini yaitu, sebagai berikut:

1. Mengetahui hasil identifikasi dan analisa penyebab waste pada proses produksi bodimobil Daihatsu Xenia komponen NX-2940 di PT. Inti Pantja Press Industri.

2. Memberikan rekomendasi perbaikan untuk mengurangi dan mengeleminasi

waste pada proses produksi bodi mobil Daihatsu Xenia komponen NX-2940

PT. Inti Pantja Press Industri.

\section{KAJIAN PUSTAKA}

\section{Lean Manufacturing}

Lean Manufacturing merupakan metode yang tepat untuk dapat

mengoptimalkan performansi dari sistem dan proses produksi karena mampu mengidentifikasi, mengukur, menganalisa dan mencari solusi perbaikan atau peningkatan performansi secara komprehensif. Konsep lean berdasarkan pada pengurangan biaya diperoleh dengan mengeliminasi waste yang berhubungan dengan semua kegiatan yang dilakukan untuk menyelesaikan pesanan dari pelanggan (Rother \& Shook, 2009). Menurut Modi \& Thakkar (2014), beberapa manfaat dari implementasi lean manufacturing yaitu sebagai berikut:

- Mengurangi biaya/ cost

- Mengurangi lead time
- Mengurangi waste

- Peningkatan produktivitas

- Peningkatan kualitas atau mengurangi defects

- Mengurangi cycle time

- Mengurangi aktivitas yang tidak perlu

- Tenaga kerja, ruang dan pemanfaatan peralatan yang lebih baik

- Mengurangi work in process inventory

\section{Pemborosan (waste)}

Waste atau pemborosan merupakan setiap aktivitas yang menggunakan sumber

daya tetapi tidak menciptakan ataupun menambah nilai atau value (Womack \& Jones,

1996). Tujuan utama dari lean manufacturing adalah mengurangi maupun menghilangkan pemborosan atau waste. Waste adalah non-value adding activities apabila dilihat dari sudut pandang customer (Hines \& Taylor, 2000).

Menurut King (2009) terdapat 7 macam pemborosan (waste) dalam Toyota

Production System (TPS) adalah sebagai berikut:

1. Waste of Over Production (kelebihan produksi) adalah pemborosan yang disebabkan produksi yang berlebih atau memproduksi lebih awal dari jadwal yang telah dibuat.

2. Waste of making defective parts adalah cacat yang terjadi akibat ketidaksempurnaan produksi atau kesalahan pada saat proses.

3. Waste of stock on hand/ inventory (persediaan yang tidak perlu) adalah dapat berupa penyimpanan inventory yang melebihi volume gudang yang ditentukan.

4. Waste of processing itself (proses yang tidak tepat) terjadi dalam situasi dimana terdapat ketidaktepatan proses/ metode operasi produksi.

5. Waste in transportation (transportasi) adalah pemindahan material dari gudang (warehouse) ke mesin, dari satu mesin ke mesin yang berikutnya, dari mesin ke gudang (warehouse). Konsep Lean menginginkan vendor mengirimkan bahan baku langsung ke tempat pengerjaan/ workshop.

6. Waste of time on hand/ waiting adalah proses menunggu kedatangan material, informasi peralatan dan perlengkapan. 


\section{Perancangan Perbaikan Proses Produksi Komponen,.. Satria Khalif Isnain1, Putu Dana Karningsih2}

7. Waste of Movement (pergerakan yang berlebihan) meliputi pergerakan terhadap material, manusia yang tidak perlu pada saat proses produksi.

\section{Identifikasi Aktivitas Nilai (Value)}

Identifikasi aktivitas yang memberikan nilai tambah dan tidak memberikan nilai

tambah merupakan proses penting dalam pendekatan lean. Dalam manufacturing dapat dikategorikan tiga jenis aktivitas menurut (Monden, 1993) yaitu, sebagai berikut:

1. Value Adding Activity (VA) Aktivitas yang dapat memberikan nilai tambah dari sudut pandang pelanggan pada suatu material produk yang dibuat atau diproses contohnya adalah sub assembly process, painting bodywork.

2. Non Value Adding Activity (NVA) aktivitas untuk membuat produk tetapi tidak memberikan nilai tambah bagi pelanggan. Aktivitas ini disebut sebagai waste yang harus dijadikan fokus utama untuk segera dihilangkan atau dieliminasi sepenuhnya. Misalkan waiting time, double handling dan stacking intermediate products

3. Necessary Non Value Adding Activity (NNVA) aktivitas yang tidak memberikan nilai tambah tetapi dibutuhkan dalam prosedur proses yang ada. Misalnya kegiatan memindahkan material, memindahkan tool dari satu tangan ke tangan yang lainnya, dan unpacking deliveries.

\section{Value Stream Mapping (VSM)}

VSM merupakan salah satu tool dari lean manufacturing yang pada awalnya berasal dari Toyota Production System (TPS) yang dikenal dengan istilah "material and information flow mapping" (Ohno, 1998). King (2009) menyebutkan bahwa VSM merupakan metode visual yang menggambarkan proses dalam hal aliran fisik material dan menciptakan nilai-nilai dari pelanggan. Termasuk didalamnya diagram tentang bagaimana arus informasi dan diproses untuk mengelola, mengendalikan atau mempengaruhi aliran material fisik.

\section{Borda Count Method (BCM)}

Borda Count Method ditemukan oleh Jean Charles de Borda, merupakan teknik

langsung untuk melakukan perhitungan peringkat dari beberapa alternatif pilihan (Nash, Zhang, \& Strawderman, 2011). Borda Count Method ini dapat digunakan untuk menentukan prioritas wastemana yang akan diselesaikan terlebih dahulu menggunakan kuesioner kepada bagian yang terkait.

\section{Root Cause Analysis-5 Why's}

Root cause analysis merupakan salah satu metode problem solving yang

digunakan untuk menemukan akar permasalahan. RCA adalah proses yang digunakan untuk mencapai penyebab utama atau penyebab masalah, karena akar penyebab masalah adalah alasan utama bahwa terjadinya masalah (Spencer, 2015). Metode 5 Why's merupakan metode analisa sederhana yang bergerak dari gejala ke pernyataan masalah dan dari proses penyebab untuk tindakan preventive. Penerapan 5 whys analysis memberikan pendekatan terstruktur yang berdasarkan fakta untuk identifikasi dan perbaikan masalah yang berfokus tidak hanya mengurangi defects tetapi juga mengeliminasinya. Solusi permanen dari permasalahan untuk mengeliminasi waste daripada hanya mereduksi waste saja (Murugaiah, 2009).

\section{Failure Mode and Effect Analysis (FMEA)}

Failure Mode and Effect Analysis

(FMEA) merupakan teknik yang terkenal

untuk perbaikan kualitas dari produk maupun proses, yang menggunakan pendekatan sistematik untuk memprioritaskan tindakan perbaikan yang berdasarkan analisa dari severity, occurrence dan detectability of failure modes (Sankar \& Prabhu, 2001). FMEA merupakan tool langkah per langkah untuk mengidentifikasi semua kemungkinan terjadinya kegagalan sepanjang proses, analisa efek menunjukkan untuk mempelajari konsekuensi dari seluruh kegagalan tersebut (Mhetre \& Dhake, 2012).

\section{Poka Yoke}

Poka Yoke dalam bahasa jepang yang berarti mencegah kesalahan merupakan

teknik yang dikembangkan oleh Shigeo Shingo pada tahun 1961. Poka Yoke menggunakan peralatan pada tool proses untuk mencegah kesalahan oleh tenaga kerja atau mesin yang menghasilkan defect. Filosofi Poka Yoke bertujuan untuk meningkatkan produktivitas dengan menyederhanakan proses, membuat lebih efisien, mengurangi jumlah kesalahan dan meningkatkan keseluruhan efisiensi dalam sistem. Poka Yoke dapat digunakan dimana saja kesalahan dapat terjadi dan dapat diimplementasikan pada setiap 


\section{Jurnal Studi Manajemen dan Bisnis}

Vol. 5 (2) 2018

proses untuk membantu pekerja, meningkatkan kualitas serta output dari proses. Poka Yoke dapat membantu mengeliminasi waste yang disebabkan oleh over production, inventory, waiting, transportation, motion dan over processing. (Miraless, Holt, Marin-Garcia, \& CanosDaros, 2011).

\section{METODE}

Penelitian ilmiah membutuhkan suatu kerangka penelitian yang sistematis dan

terarah berdasarkan permasalahan yang ditinjau agar proses penelitian dan hal yang diperoleh tepat sasaran. Secara umum alir penelitian yang dilakukan terangkum pada Gambar 1.3.

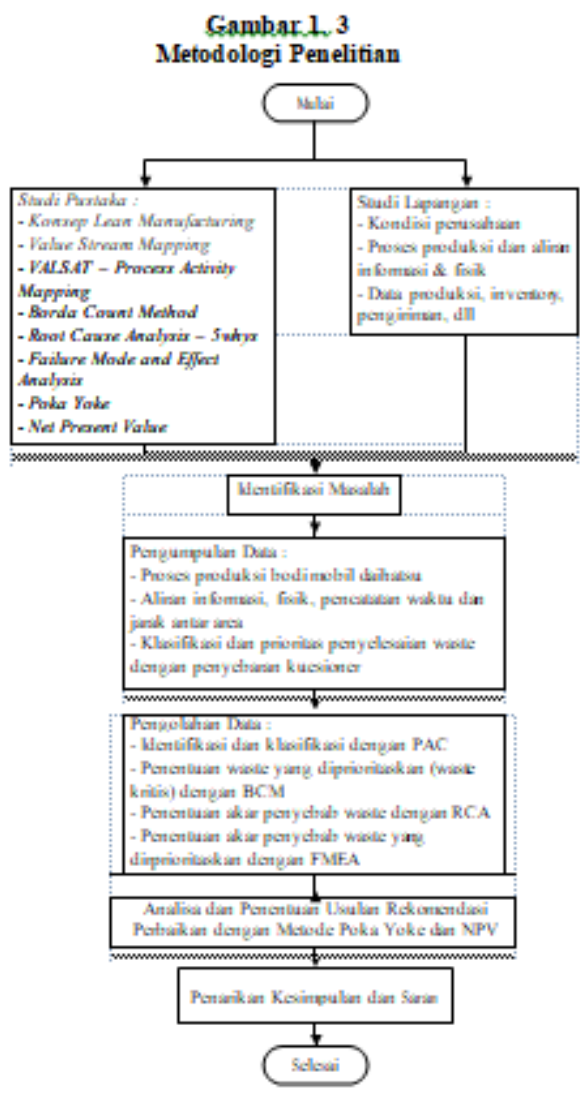

\section{PEMBAHASAN}

Berdasarkan hasil dari value stream mapping maka dapat diketahui bahwa terdapat downtime pada proses press yaitu sebesar 25\%, hal ini disebabkan terjadi dies trouble selama 15 menit dalam 60 menit proses produksi. Selain itu dapat diketahui juga bahwa masih terdapat produk defect di lantai produksi yaitu pada proses press sebesar $0,47 \%$ hal ini terjadi karena pada saat proses press terjadi part minus atau pecah, shockline dan baret sehingga produk langsung reject karena tidak dapat di-repair. Defect pada proses subassy sebesar $0,38 \%$ hal ini terjadi karena spot meleset pada saat proses dan defect yangterbesar di area prepared delivery yaitu sebesar $20 \%$ hal ini terjadi karena disebabkan oleh beberapa hal yaitu karena musim hujan, area warehouse yang terbuka serta finish part disimpan lebih dari satu hari yang menyebabkan timbulnya karat, dan karat ini biasanya terjadi setelah produk di pallet diberi tag OK oleh bagian quality assurance.

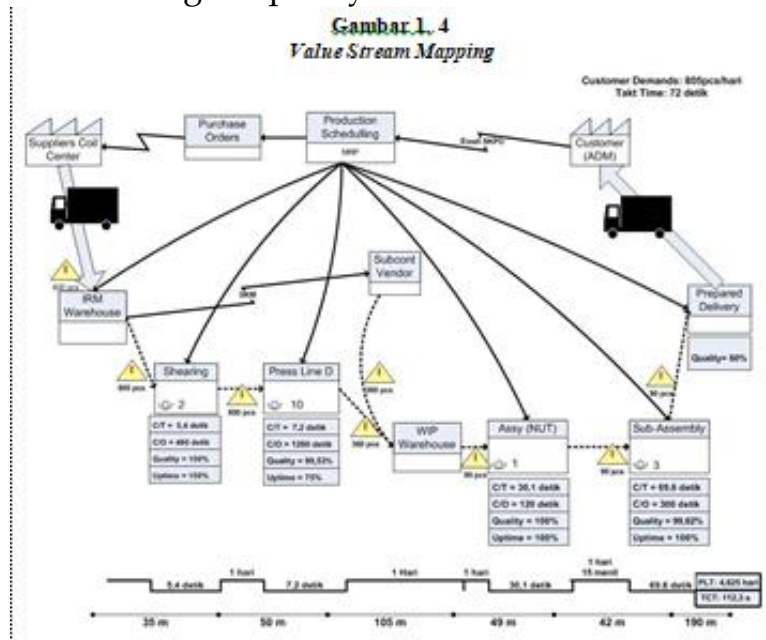

Berdasarkan pemetaan proses produksi yang digambarkan dalam Value Stream Mapping pada Gambar 1.4, dapat dilihat bahwa untuk memproduksi produk NX-2940 dengan total 90 pcs dalam 4 pallet dibutuhkan waktu process lead time sebesar 4,625 hari.

Penentuan Waste Kritis dengan Borda Count Method

Penggunaan metode BCM ini dengan melakukan penyebaran kuesioner kepada

responden sebanyak lima orang kepada bagian yang terkait dan bertanggung jawab langsung pada proses produksi, yaitu supervisor beberapa bagian, inventory raw material (IRM), production planning control (PPC), produksi, quality assurance (QA), dan inventory finish part (IFP). Berdasarkan hasil dari kuesioner identifikasi waste kritis dengan Borda Count Method bahwa waste kritis yang segera perlu ditangani pada lantai produksi PT. Inti Pantja Press Industri adalah waste waiting dan waste defect. Hal ini terjadi karena kedua waste tersebut memiliki dampak pemborosan yang cukup signifikan terhadap 2 area penting di lantai produksi PT. Inti Pantja Press Industri, yaitu area subassy dan area prepared delivery.

Analisa Akar Penyebab Waste Kritis dengan 5 Why's 


\section{Perancangan Perbaikan Proses Produksi Komponen,.. Satria Khalif Isnain1, Putu Dana Karningsih2}

Analisa akar penyebab permasalahan yang memicu terjadinya waste kritis dengan menggunakan Root Cause Analysis (RCA) dengan menggunakan 5 Why's Analysis melibatkan beberapa expert di perusahaan. Berikut ini merupakan hasil brain storming 5 Why's untuk waste waiting dan waste defects yang ditunjukkan pada Tabel

1.2. Hasil analisa akar pernyebab permasalahan waste kritis ini berdasarkan diskusi dan keadaan aktual yang terjadi pada proses produksi di PT. Inti Pantja Press Industri.

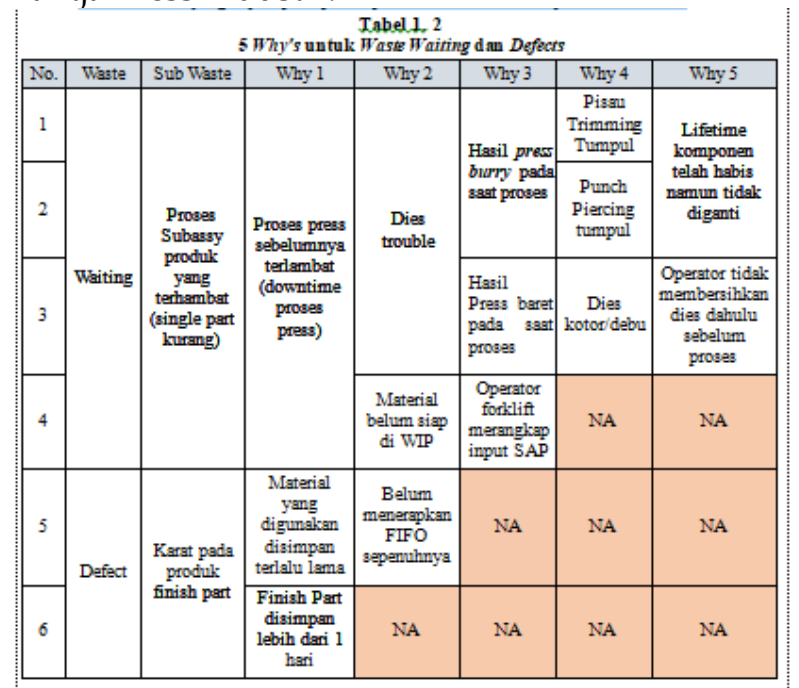

Berdasarkan Tabel 1.2 dapat dilihat pada sub waste untuk waste waiting yaitu proses subassy produk terhambat atau terjadi bottleneck pada proses produksi disebabkan oleh beberapa akar permasalahan, yaitu terjadi dies trouble pada proses press dan operator forklift merangkap input SAP yang berakibat material sheet belum siap di work in process (WIP).Sedangkan pada sub waste untuk waste defects yaitu terjadi karat pada produk finish part yang disebabkan oleh beberapa akar permasalahan, yaitu belum menerapkan sistem first in-first out (FIFO) sepenuhnya pada material dan finish part disimpan lebih dari 1 hari.

\section{Penentuan Akar Penyebab Masalah Waste Kritis} dengan FMEA

Setelah didapatkan akar penyebab permasalahan pada tiap waste kritis waiting dan defects dengan menggunakan Root Cause Analysis -5 Why's, maka selanjutnya dilakukan penetuan prioritas Root Cause yang akan diberikan rekomendasi perbaikan dengan mencari Risk Priority Number (RPN) pada setiap waste kritis tersebut. RPN didapatkan dengan mengalikan nilai dari severity, occurrence, dan detection. Selanjutnya berdasarkan hasil RPN tersebut akan didapatkan untuk lebih fokus pada permasalahan yang mana dan memberikan rekomendasi perbaikan. Berikut ini merupakan hasil rekap RPN tiap potential cause pada tiap waste kritis yang diurutkan berdasarkan RPN tertinggi pada Tabel 1.3. Potential cause dengan RPN tertinggi inilah yang nantinya akan diprioritaskan untuk diberikan rekomendasi perbaikan.

Tabel 1, 3

\begin{tabular}{|c|c|c|c|c|}
\hline \multicolumn{5}{|c|}{ Iasil Pengurutan RPN FMEA Seluruh Waste Kritis } \\
\hline No. & Taste & $\begin{array}{c}\text { Potential Failure } \\
\text { Mode }\end{array}$ & Potential Cause & RPN \\
\hline 1 & \multirow{3}{*}{ Waiting } & \multirow{3}{*}{$\begin{array}{l}\text { Proses Subsasy } \\
\text { produk yang } \\
\text { terhambat (single } \\
\text { part kurang) }\end{array}$} & $\begin{array}{c}\text { Operator tidal: } \\
\text { membersihksn dies } \\
\text { dahulu sebelum proses }\end{array}$ & 224 \\
\hline 2 & & & $\begin{array}{c}\text { Lifetime komponen } \\
\text { telah habis namun tidak } \\
\text { diganti }\end{array}$ & 168 \\
\hline 3 & & & $\begin{array}{c}\text { Operator forklift } \\
\text { merangksp input SAP }\end{array}$ & 98 \\
\hline 4 & \multirow[b]{2}{*}{ Defect } & \multirow{2}{*}{$\begin{array}{l}\text { Karat pada produk } \\
\text { finish part }\end{array}$} & $\begin{array}{l}\text { Finish Part disimpan } \\
\text { lebih dari } 1 \text { hari }\end{array}$ & 168 \\
\hline 5 & & & $\begin{array}{l}\text { Material belum } \\
\text { menersplsan FIFO } \\
\text { sepenuhnya }\end{array}$ & 105 \\
\hline
\end{tabular}

\section{Rekomendasi Perbaikan}

Setelah didapatkan akar permasalahan dari tiap waste kritis menggunakan Root Cause Analysis dan mengurutkan prioritasnya menggunakan Failure Mode and Effect Analysis maka dapat ditentukan akar permasalahan mana yang perlu segera ditangani untuk diberikan rekomendasi perbaikan. Rekomendasi perbaikan ini nantinya diharapkan dapat mengurangi maupun mengeliminasi waste yang terjadi sehingga proses produksi lebih efisien. Berikut ini merupakan rekomendasi perbaikan yang dapat diusulkan penulis terhadap akar permasalahan dari tiap waste kritis.

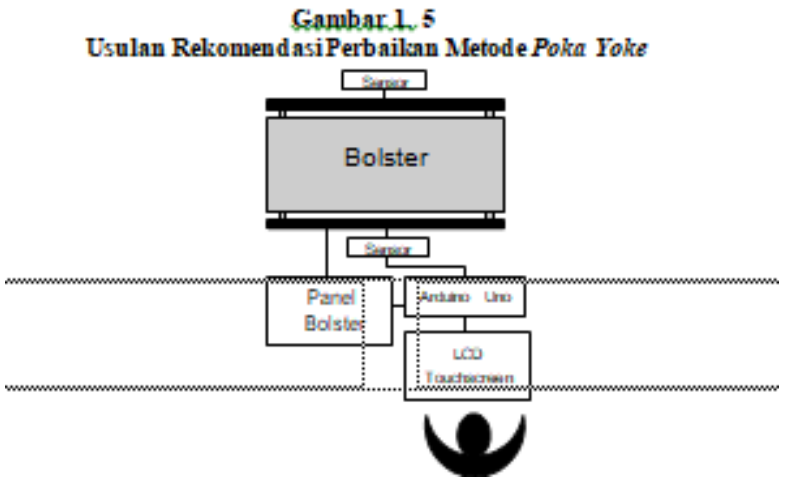

Penerapan rekomendasi ini diharapkan mampu mengurangi downtime pada proses press yang disebabkan karena operator harus membersihkan dies saat proses press sedang berjalan/ berlangsung. Berdasarkan sumber permasalahan yang diperoleh dari hasil RCA dan FMEA terkait finish part disimpan lebih dari satu hari untuk mengurangi permasalahan waste tersebut maka rekomendasi yang dapat diusulkan yaitu 


\section{Jurnal Studi Manajemen dan Bisnis \\ Vol. 5 (2) 2018}

pemasangan wrapping pada pallet finish part setiap akhir minggu atau hari jumat. Usulan rekomendasi ini dilakukan karena area warehouse finish part/ prepared delivery masih terbatas. Berdasarkan hasil perbandingan biaya yang dikeluarkan oleh perusahaan untuk mengatasi karat yang terjadi pada produk finish part maka hasilnya lebih murah untuk pemasangan wrapping pada pallet produk finish part, sehingga usulan rekomendasi perbaikan ini layak untuk dilakukan.

\section{SIMPULAN DAN SARAN \\ Kesimpulan}

Berdasarkan hasil analisa dan pembahasan yang dilakukan pada penelitian di

PT. Inti Pantja Press Industri, maka dapat ditarik beberapa kesimpulan sebagai berikut:

1. Hasil identifikasi permasalahan waste yang terjadi berdasarkan VSM dan BCM

maka diketahui pada lantai produksi terdapat waste kritis waiting dan defect.

2. Waste waiting yang terjadi disebabkan oleh proses subassy yang terhambat atau terjadi bottleneck yang memiliki disebabkan oleh operator tidak membersihkan dies sebelum proses.

3. Waste defect yang terjadi disebabkan oleh karat pada produk finish part yang memiliki akar permasalahan finish part disimpan lebih dari 1 hari.

4. Rekomendasi perbaikan yang diusulkan untuk permasalahan operatortidak membersihkan dies sebelum proses yaitu penerapan metode Poka Yoke untuk operator membersihkan dies sebelum proses press. Sedangkan rekomendasi perbaikan untuk finish part disimpan lebih dari 1 hari yaitu pemasangan wrapping roll pada pallet finish part setiap akhir minggu atau hari Jumat.

\section{DAFTAR PUSTAKA}

Hines, P., \& Taylor, D. (2000). Going Lean. Cardiff, United Kingdom: Cardiff Business

School, Lean Enterprise Research Centre.

King, P. L. (2009). Lean for the Proces Industries : Dealing with Complexity. New
York: CRC Press, Taylor \& Francis Group.

Mhetre, R. S., \& Dhake, R. J. (2012). Using Failure Mode Effect Analysis in Precision Sheet Metal Parts Manufacturing Company. International Journal of Applied Sciences and Engineering Research, 1(2), 302 - 311.

Miraless, C., Holt, R., Marin-Garcia, J. A., \& CanosDaros, L. (2011). Universal design of Workplace Through The Use of Poka-Yokes: Case Study and Implications. Journal of Industrial Engineering and Management, 4(3), 436-452. Retrieved from www.jiem.org

Modi, D. B., \& Thakkar, H. (2014, March). Lean Thinking: Reduction of Waste, Lead Time, Cost through Lean Manufacturing Tools and Technique. International Journal of Emerging Technology and Advanced Engineering, 4(3), 339 - 334. Retrieved from www.ijetae.com

Monden, Y. (1993). Toyota Production System: An Integrated Approach to Just-in-time.

Norcross: Industrial Engineering and Management Press.

Murugaiah, U. (2009). Scrap Loss Reduction using 5-whys Analysis. International

Journal of Quality \& Reliable Management, 27(5), 527-540.

Nash, K., Zhang, H., \& Strawderman, L. (2011). Empirical Assessment of Decision Making Behavior in Multi-Criteria Scenarios. Industrial Engineering Research Conference. Mississippi.

Ohno, T. (1998). Toyota Production System: Beyond Large Scale Production. Oregon

Rother, M., \& Shook, J. (2009). Learning to SeeValue-Stream Mapping to Create Value and Eliminate Muda. Cambridge: Lean Enterprise Institute.

Sankar, N. R., \& Prabhu, B. S. (2001). Modified Approach for Prioritization of Failures in a System Failure Mode and Effects Analysis. International Journal of Quality and Reliability Management, 18(3), 324-335.

Spencer, K. (2015). Getting the Root Cause. qualitymag.com.

Womack, J. P., \& Jones, D. I. (1996). Lean Thinking: Banish Waste and Create Wealth in Your Corporation. New York: Simon \& Schuster. 